\title{
ФОРМИРОВАНИЕ У КИТАЙСКОЙ АУДИТОРИИ МЕЖКУЛЬТУРНОЙ КОМПЕТЕНЦИИ В ПРОЦЕССЕ ИЗУЧЕНИЯ ПРЕДМЕТА «РЕГИОНАЛЬНАЯ ГЕОГРАФИЯ РОССИИ»
}

\section{FORMATION OF INTERCULTURAL COMPETENCE IN THE CHINESE AUDIENCE IN THE PROCESS OF STUDYING THE SUBJECT "REGIONAL GEOGRAPHY OF RUSSIA"}

Wang Chunhun

Summary: in the present article the formation at the Chinese audience of cross-cultural competence of process of studying the subject "Regional Geography of Russia" is considered. Various definitions of the categories "intercultural communication", "intercultural competence" are presented. It describes the current methods of formation and development of intercultural competence. The role of the subject "Regional Geography of Russia" in the system of teaching Russian as a foreign language among the Chinese audience is shown. It is justified that in the process of teaching the Russian language as a foreign language, it is important to form not only linguistic knowledge and skills among the Chinese audience, but also intercultural competencies, without which it is impossible to master the Russian language. The prerequisites of formation of intercultural competence among the Chinese audience in the process of studying the subject "Regional Geography of Russia" by the method of textbook analysis are analyzed. The author concludes that the formation and development of intercultural competence among the Chinese audience increases the level of intercultural communication, ensures the success and effectiveness of communication. At the same time, regional geography plays an important role in the system of teaching the Russian language as a foreign language, in particular, students have increased interest in the country and their motivation for learning the Russian language is increased.

Keywords: Russian as a foreign language, regional geography, cultural competence, intercultural communication, background knowledge, intercultural competence, Chinese audience, foreign language, linguistic knowledge.

\author{
Ван Чуньхун \\ доцент, Цзилиньский педагогический университет \\ (Сыnuн, KHP) \\ wch3625139@yandex.ru
}

Аннотация: В настоящей статье рассматривается формирование у китайской аудитории межкультурной компетенции в процессе изучения предмета «Региональная география России». Представлены различные определения категорий «межкультурная коммуникация», «межкультурная компетенция». Дается характеристика актуальным методикам формирования и развития межкультурной компетенции. Показана роль предмета «Региональная география России» в системе обучения русскому языку как иностранному у китайской аудитории. Обосновывается, что в процессе обучения русскому языку как иностранному важно сформировать у китайской аудитории не только лингвистические знания и умения, но и межкультурные компетенции, без которых невозможно овладение русским языком. Анализируются предпосылки формирования у китайской аудитории межкультурной компетенции в процессе изучения предмета «Региональная география России» методом анализа учебников. Автор приходит к выводу о том, что формирование и развитие межкультурной компетенции у китайской аудитории повышает уровень межкультурной коммуникации, обеспечивает успешность и эффективность общения. При этом, страноведение играет важную роль в системе обучения русскому языку как иностранному, в частности у студентов повышается интерес к стране и усиливается их мотивированность к изучению русского языка.

Ключевые слова: русский язык как иностранный, страноведение, культуроведческая компетенция, межкультурная коммуникация, фоновые знания, межкультурная компетенция, китайская аудитория, иностранный язык, лингвистические знания.
И зучение иностранных языков на современном этапе тесно связано с понятием межкультурной компетенции. В значительной степени взаимодействие китайской аудитории с представителями российской культуры все более положительно влияют на мотивацию студентов к изучению русского языка. При этом, следует отметить, что само по себе хорошее знание русского языка китайскими студентами не является гарантом успешной межкультурной компетенции. Так, возможное непонимание или непринятие студентами культуры, обычаев, традиций и норм поведения страны изучаемого языка, вызывают сложности в межкультурной коммуникации и, например, как следствие - потеря возможного выгодного эффекта от делового партнерства. В связи с этим, на сегодняшний день существует необходимость в формировании у изучающих русский язык как иностранный ключевых компетенций, позволяющих осуществлять успешную коммуникацию в услови- 
ях межкультурного общения.

Прежде чем дать определение термину «межкультурная компетенция», сначала нужно уточнить понятие «межкультурной коммуникации», при которой названная компетенция необходима каждому обучающемуся иностранным языкам. Определения межкультурной коммуникации некоторых ученых представлены на рисунке 1. В указанных определениях термина «межкультурной коммуникации» можно выделить две общих черты:

1) этим термином называется адекватное взаимопонимание двух участников коммуникативного акта, принадлежащих к разным национальным культурам [3, с. 26];

2) это общение языковых личностей, принадлежащих к различным лингвокультурным сообществам [4, с. 51];

3) это когнитивно-коммуникативная среда, в которой происходит интеракция представителей различных культур с помощью вербальногоневербального кода в би- или поликультурном контексте, способствующем сравнению культур, выделению общего и специфического и достижению понимания [15, с. 18];

4) это форма коммуникации двух или более представителей различных культур, в ходе которой происходит обмен информацией и культурными ценностями взаимодействующих культур $[13$, с. 95$]$;

5) межкультурная коммуникация представляет собой один из видов вербальных коммуникаций, происходящий в определенной коммуникативной ситуации и совершаемый коммуникантами, принадлежащими к различным культурам на одном (родном или изучаемом) языке [19, с. 22].

Рис. 1. Определение термина «межкультурная компетенция»

1) это умение общаться с представителями другой культуры, включающее способность к пониманию ограниченности своей собственной культуры и своего собственного языка, и умение переключиться при встрече с другой культурой на другие не только языковые, но и неязыковые нормы поведения [9, с. 4];
2) это компетенция особой природы, основанная на знаниях и умениях способность осуществлять межкультурное общение посредством создания общего для коммуникантов значения происходящего и достигать в итоге позитивного для обеих сторон результата общения [7, с. 236];
3) под межкультурной компетенцией подразумевается способность эффективно и надлежащим образом общаться с представителями другой культуры [18, с. 100].

Рис. 2. Определения категории «межкультурная компетенция» 
- межкультурная коммуникация - это один из видов коммуникации или общения, в котором происходит взаимодействие двух или больше участников;

- участниками межкультурной коммуникации являются представители разных лингвокультурных групп.

К исследованию процессов формирования и развития межкультурной компетенции при обучении иностранным языкам более подходит следующее определение межкультурной коммуникации: это коммуникация, совершаемая двумя или более представителями различных лингвокультурных групп из разных стран на одном языке, который является родным для одной стороны и иностранным для другой; при такой коммуникации порождается новый акт общения, который обычно не проявляется в общении между коммуникантами с одним и тем же родным языком; желаемый результат такой коммуникации - достижение взаимопонимания.

Для формирования у китайской аудитории межкультурной компетенции носители китайского языка должны не только осваивать языковые знания (фонетика, лексика, грамматика русского языка), обладать речевыми умениями, но и иметь представление о русской культуре.

Некоторые определения межкультурной компетенции российских и зарубежных ученых представлены на рисунке 2.

По нашему мнению, «межкультурная компетенция»: это разновидность коммуникативной компетенции, включающая в себя ряд знаний, умений и навыков на языковом (фонетика, лексика, грамматика), речевом (речевая деятельность и речевой этикет), культурном и психологическом уровне, обеспечивающих говорящему на иностранном языке возможность осуществлять коммуникацию с носителями изучаемого языка и достигать в итоге позитивного для обеих сторон результата общения.
Методика формирования и развития межкультурной компетенции рассматривается в ряде исследований [1, $11,17]$ по аспектам, представленным на рисунке 3.

Отметим, что страноведение играет важную роль в системе обучения русскому языку как иностранному и в процессе формирования межкультурной компетенции, в том числе у китайской аудитории.

Нередко в коммуникации между русскими и китайцами возникают препятствия именно из-за недостатка страноведческих знаний. Общение с иностранцами - это постоянное межкультурное обучение, интеркоммуникация. Для взаимопонимания между носителями разных языков очень важно уметь преодолевать трудности, возникающие при взаимодействии разных культур, обусловленных различным историческим, политическим и культурным развитием. Чтобы избежать непонимания, необходимо знать национальные особенности, традиции и обычаи друг друга [18, с. 32-33].

Например, русские очень любят хризантемы. Они дарят их родственникам и друзьям на день рождения или праздник. В Китае отношение к хризантеме противоположное: китайцы приносят их только умершим. Сорока в Китае - символ счастья. Эта птица означает удачу и считается «птицей удовольствия». Сорока же в русской культуре символизирует «зловредную болтливость, вороватость, стяжательство» [16, с. 667].

Межкультурные различия, мешающие пониманию, называют «культурными лакунами». Учащийся часто переносит нормы родного языка на язык изучаемый, сам того не осознавая. Такой перенос нередко порождает ошибки в изучаемом языке. Такие ошибки могут возникать также на грамматическом и лексико-семантическом уровнях, например, китайские студенты говорят «есть лекарство» вместо «принять лекарство», «через помощь» вместо «при помощи» $[12$, с. 43].
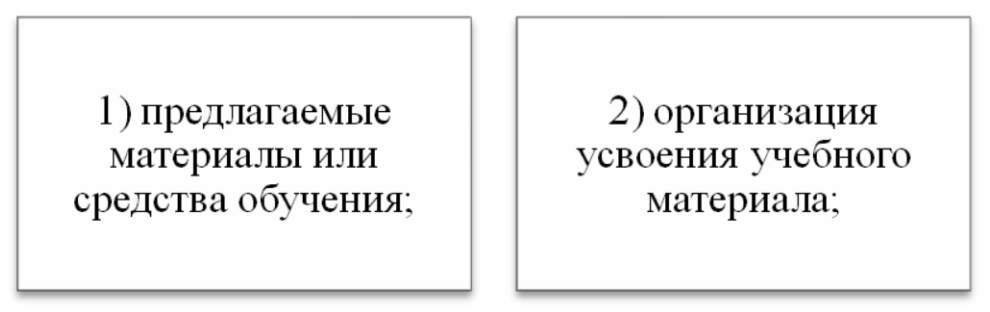

3) основной подход к обучению, принципы обучения и путь их реализации;
4) оценивание уровня межкультурной компетенции.

Рис. 3. Некоторые аспекты методики формирования и развития межкультурной компетенции 
На занятиях по русскому языку студенты знакомятся с культурой страны изучаемого языка, учатся аспектам межкультурной коммуникации. Практически на любом занятии по русскому языку как иностранному можно использовать страноведческий и лингвострановедческий материалы. Подобная практика усиливает мотивированность китайских студентов к изучению русской речи [10, c. 223].

Таким образом, в процессе обучения русскому языку как иностранному важно сформировать у студентов не только лингвистические знания и умения, но и межкультурные компетенции, без которых невозможно овладение русским языком.

В связи с этим, рассмотрим предпосылки формирования страноведческой компетенции у китайской аудитории методом анализа учебников.

Анализ учебников по изучению русского языка как иностранного, по которым обучаются китайские студенты показал следующее. В серии учебников «На восток» Ши Тиетян [14] содержится множество примеров, относящихся к аспектам лингвострановедения и лингвокультурологии, ориентированных на китайскую аудиторию. Стоит отметить, что в данных учебниках представлены все необходимые фоновые знания о стране изучаемого языка с учётом уровня обучающихся. Некоторые из текстов посвящены российско-китайским отношениям; они повествуют о русском студенте, который изучает китайский язык, или о китайском студенте, который учится в России.

Одним из наиболее популярных в Китае учебников по русскому языку является «Дорога в Россию» В.Е. Антоновой [2]. Актуальные и интересные материалы о жизни в России, познавательный характер текстов, подробные комментарии и тренировочные упражнения делают пособия хорошим средством обучения русскому языку как иностранному.

В учебнике Дай Гуйцзюй «География России» [5] информация о культуре России, на наш взгляд, представлена недостаточно широко и ограничена лишь перечислением отдельных фактов.

Полагаем, с целью успешного формирования у китайской аудитории межкультурных компетенций в процессе изучения страноведения России преподавателям целесообразно использовать дополнительные материалы о регионах России, национальном составе и культуре народов, проживающих на территории Российской Федерации». В связи с этим, интерес представляет разработанная Е.В. Дишкант, Ли Шуци [6, с.55] система уроков, направленных на формирование у китайской аудитории межкультурной компетенции, расширение словарного запаса студентов, развитие устной и письменной, моно- логической и диалогической речи.

Авторами презентован блок уроков по теме «Золотое кольцо России» [6, с. 56]. Проанализируем некоторые приемы и методы работы в иностранной аудитории для успешного формирования межкультурной компетенции в процессе изучения страноведения России. Так, в начале занятия по теме «Белокаменная архитектура Владимира» предлагается провести предварительную работу по расширению лексического запаса иностранных студентов (креститель, княжество, резиденция, икона), предложить культурологический комментарий к именам исторических деятелей: Андрея Боголюбского, Юрия Долгорукого, Андрея Рублёва. Затем предлагается продемонстрировать учебный фильм об архитектуре Владимира, знакомящий с достопримечательностями города. Для развития навыков аудирования студентам предлагается задание по восстановлению текста.

Второй блок послетекстовых заданий включает в себя упражнения по лексико-грамматическим темам, вызывающим наибольшие трудности у студентов. Например, от каких глаголов и при помощи каких суффиксов образованы данные существительные: заказчик, резчик, ценитель, роспись.

В завершении предлагается составить студентам, совместно с преподавателем, план текста и последующий его пересказ. В качестве домашнего задания предлагается составление диалога на тему «Путешествие по Владимиру».

Следующее занятие на тему «Ростов Великий» авторами предлагается провести в виде ролевой игры [6, с. 57]. В начале урока преподаватель объясняет лексическое значение слов: язычник, крестить, благословить, битва, подвижник. Знакомит с культурно-историческими реалиями и историческими деятелями (Ярославом Мудрым, Юрием Долгоруким, Андреем Боголюбским). Затем демонстрируется учебный фильм, задаются вопросы. В качестве закрепления изученного материала предлагаются ролевые ситуации.

Также авторами предлагается провести в форме виртуальной экскурсии занятие на тему «Путешествие по старинным городам «Золотого кольца России»: Сергиеву Посаду, Ярославлю, Костроме, Плёсу». В данном случае преподаватель выступает в роли экскурсовода, а студенты - туристов. Получив путеводитель, содержащий сведения о маршруте и основных достопримечательностях городов, прослушав «экскурсовода», «туристы» должны задать вопросы, обменяться впечатлениями о поездке.

Таким образом, к каждому уроку подбирается соответствующий грамматический, текстовый, лексический материал, в котором отражаются культура, история, достопримечательности России, что, по нашему мнению, 
способствует эффективному формированию у китайской аудитории межкультурной компетенции.

Полагаем, что обучение русскому языку как иностранному должно сопровождаться изучением предмета «Региональная география России», так как осуществление процесса коммуникации на русском языке невозможно без знаний географии, истории, культуры России и формирования общих, социокультурных и межкультурных компетенций.

По нашему мнению эффективность обучения русскому языку и формирования межкультурных компетенций у китайской аудитории повысится, если:

- создать систему обучения русскому языку с использованием страноведческого материала;

- расширять словарный запас учащихся страноведческой лексикой;

- проводить работу по развитию связной речи на основе изучения русской культуры.

Исследование, проведенное в рамках данной статьи, позволяет прийти к следующим выводам:
1. Формирование и развитие межкультурной компетенции у китайской аудитории помогает повысить уровень межкультурной коммуникации, обеспечивает успешность и эффективность общения. Усвоение межкультурной компетенции в процессе изучения страноведения России помогает «достигать в итоге позитивного для обеих сторон результата общения».

2. Страноведение играет важную роль в системе формирования у китайской аудитории межкультурной компетенции. На занятиях по русскому языку китайские студенты знакомятся с российской культурой, учатся диалогу культур. Практически на любом уроке можно использовать лингвострановедческий компонент. Это повышает интерес к стране и усиливает мотивированность китайских студентов к изучению русского языка.

3. Формирование межкультурных компетенций у китайских студентов в процессе изучения страноведения России является продуктивным способом совершенствования их профессиональной подготовки.

\section{ЛИТЕРАТУРА}

1. Алмазова Н.И. Когнитивные аспекты формирования межкультурной компетентности при обучении иностранному языку в неязыковом вузе: автореф. дис. ... д-ра. пед. наук: 13.00.02. - Санкт-Петербург: ФИНЭК, 2003. - 47 с.

2. Антонова В.Е. Дорога в Россию: граммат. коммент. и слов. к учеб. для говорящих на кит. яз. (элементар. уровень). 2-е изд. - М.; 3 латоуст: ЦМО МГУ, 2004. $-256 \mathrm{c}$

3. Верещагин Е.М., Костомаров В.Г. Язык и культура: Лингвострановедение в преподавании русского языка как иностранного - 4-е изд., перераб. и доп. М.: Русский язык, 1990. - 246 с.

4. Гудков Д.Б. Теория и практика межкультурной коммуникации. - М.: ИТДГК «Гнозис», 2003. - 288 с.

5. Дай Гуйцзюй. География России. - Пекин: Обучение иностр. яз. и исслед. 2005. - 170 с.

6. Дишкант Е.В., Ли Шуци Применение страноведческих материалов на уроках русского языка как иностранного в китайской аудитории // Вестник ЮжноУральского гуманитарного педагогического университета. 2018. №8. С. 49-63

7. Елизарова Г.В. Культура и обучение иностранным языкам - СПб.: КАРО, 2005. - 352 с.

8. Игнатьева Е.А. Лингвокультурологический аспект преподавания русского языка как иностранного / Сб. ст. Х Межд. науч.-практ. конф. «Современная наука: проблемы и перспективы» (Ставрополь, 01-30 апреля 2018 г.). - Ставрополь: Центр научного знания «Логос», 2018. - С. 60-64.

9. Методика межкультурного образования средствами русского языка как иностранного. Книга для преподавателя / А.Л. Бердичевский [и др.] М.: Русский язык. Курсы, 2011. - 184 с.

10. Нурхамитов М.Р. Лингвострановедческий материал как средство формирования межкультурной компетенции при обучении иностранному языку // Воспитание и обучение: теория, методика и практика: материалы VI Междунар. науч.-практ. конф. (Чебоксары, 20 март 2016 г.). В 2 т. / редкол.: 0.Н. Широков [и др.]. - Чебоксары: ЦНС «Интерактив плюс», 2016. - Т. 1. - С. 354-355.

11. Павлова Л.П. Исследование влияния игровой учебной деятельности на формирование межкультурной компетенции студента вуза (на материале иностранного языка): автореф. дис. ... канд. пед. наук: 13.00.08. Ставрополь, 2004. - 23 с.

12. Пань Хэн. Аккультурация в процессе чтения лекций по русскому языку в китайской аудитории // Ученые записки Комсомольского-на-Амуре государственного технического университета. 2015. № 4 (20). С. 43-46.

13. Садохин А.П. Введение в теорию межкультурной коммуникации. - М.: Высш. шк., 2005. - 310 с.

14. Тиетян Ш. На восток: учебник. - Пекин: Пекинский университет иностранных языков. 2015. - 376 с.

15. Фурманова В.П. Межкультурная коммуникация в теории и практике преподавания иностранных языков в вузе: монография / В.П. Фурманова. Саранск: Изд-во Морд. гос. ун-та, 2009. - 163 с.

16. Хао Ц., Кошелева Е.Ю. Фразеологизмы китайского и русского языков, содержащих зоонимы: сопоставительный анализ // Молодой ученый. 2015 . № 11. C. 1701-1703.

17. Чабала Т.В. Проектно-проблемный подход в развитии межкультурных компетенций педагогов: автореф. дис. . . . канд. пед. наук: 13.00.08. - Воронеж, 
2005. -22 c.

18. Hu Wenzhong. Intercultural communication: teaching and research (in Chinese and English). - Beijing: Foreign language teaching and research press, 2015. $321 \mathrm{p}$.

19. Wu Wenshan. General Theory of Intercultural Communication / Wenshan Wu, Huixian Yan. - Beijing: The commercial press, 2009 (re. ed. 2015 ). - 242 p.

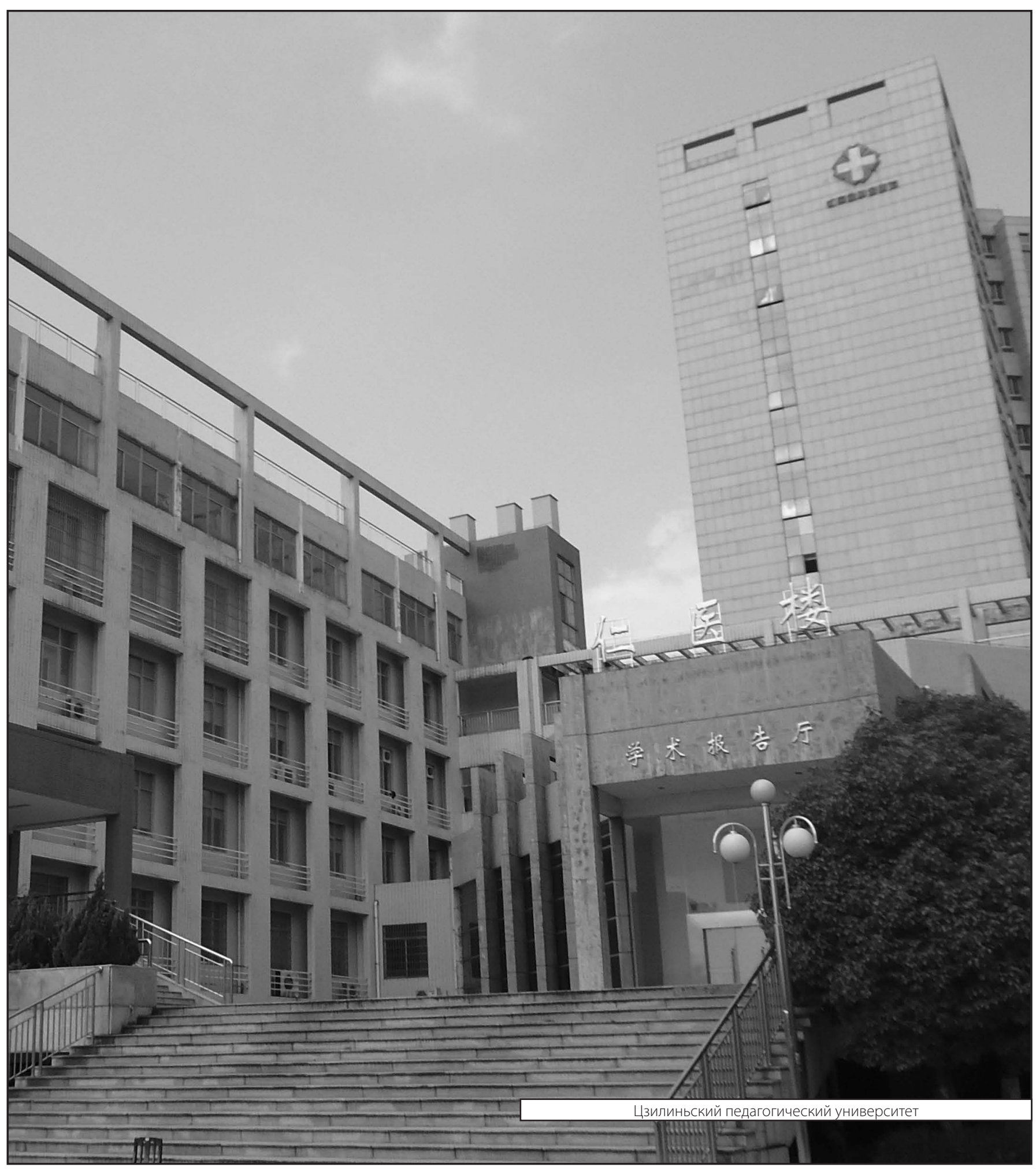

